\title{
AT MAGESKIFTE DET TIMELIGE MED DET ANDELIGE
}

\section{Religiøs gavegivning i vesteuropæisk middelalder}

\author{
Af Per Ingesman
}

\section{I}

Den franske sociolog Marcel Mauss' bog Essai sur le don fra 1923-24 har som bekendt været en af de mest indflydelsesrige bøger i moderne socialantropologi. Teorien om gavegivningen som et socialt fænomen af afgørende betydning $\mathrm{i}$ en række traditionelle samfund har vist sig uhyre frugtbar og anvendelig, ikke blot inden for sociologi og socialantropologi i studiet af nutidige samfund, men også i fag, der beskæeftiger sig med kultur og religion i fortidige samfund: arkæologi, historie, religionshistorie osv.

Kernen i Mauss' synspunkt er, at givning af en gave etablerer et bånd mellem den, der giver gaven, og den, der modtager den. Givning af en gave medfører forpligtelsen for modtageren til at acceptere gaven og give noget til gengæld. Derved etableres en udveksling mellem gavegiver og gavemodtager.

For historiens vedkommende har det især været inden for middelalderforskningen, at Mauss har fundet anvendelse. Det er naturligvis ikke noget tilfælde. I vesteuropæisk middelalder har man jo, hvad der må være en af de største kollektive gavegivningsprocesser i menneskehedens historie: den tusind år lange proces, strækkende sig fra den tidligste middelalder og helt frem til umiddelbart før reformationen, hvorunder kolossale rigdomme, fra jordbesiddelser og bygningsværker til naturalier, penge, brugsgenstande og kunstværker, af fromme troende skænkedes til den kristne kirke.

I sin inderste kerne var drivkraften religiøs: Det var ønsket om sjælens frelse - eller frygten for fortabelsen - der var baggrunden for gaverne til kirken. Men det er klart, at også andre, mere verdslige motiver kan have spillet ind på linie med de religiøse - og i hvert fald klart, at den kolossale overførsel af rigdomme til kirken havde dybtgående sociale, politiske og $\emptyset$ konomiske konsekvenser. Tag blot godsgaverne til kirken, der bragte så 
store godsmængder i kirkens besiddelse, at hele magtbalancen i det middelalderlige samfund forrykkede sig derved (Ingesman 1993, 143).

Spørgsmålet er nu: Opnår vi en bedre forståelse af denne proces ved at betragte den med udgangspunkt i Mauss' gavegivningsteori? Altså f.eks. ved at se nærmere på de relationer, der etableredes mellem personer, der gav gaver til kirken, og de kirkelige institutioner, sognekirker, domkirker, klostre osv., der stod som modtagere af de pågældende gaver.

Af middelalderhistorikere blev Mauss først anvendt på det franske og burgundiske område $\mathrm{i}$ overgangen mellem tidlig middelalder og højmiddelalder omkring år $1000 .{ }^{1}$ Her fandt de grundlæggende donationer til kirken sted, og her havde man et samfund med en svag centralmagt og en ringe udviklet pengeøkonomi, hvilket skulle gøre det nemmere at iagttage gavegivningens sociale, politiske og økonomiske funktioner. Et udmærket eksempel på benyttelsen af Mauss giver Barbara H. Rosenweins bog To Be the Neighbor of Saint-Peter. The Social Meaning of Cluny's Property 909-1049 fra 1989. På grundlag af en analyse af næsten 2.500 ejendomsoverførsler fra overklassen til klostret i Cluny konkluderer Rosenwein, at hovedformålet var at etablere relationer mellem giver og modtager. Overførslerne af jord virkede socialt sammenbindende $i$ en periode præget af opløsningstendenser. Gaverne skabte og vedligeholdt forbindelser mellem de givende adelsfamilier og klostret. I et studie af det samme burgundiske område $i$ en lidt senere periode har Constance Bouchard peget på det samme. I sin bog om ejendomsoverførsler til 1100-tallets modeorden cistercienserne, Holy Entrepreneurs. Cistercians, Knights, and Economic Exchange in Twelfth-Century Burgundy fra 1991, fokuserer Bouchard igen på klostrenes forhold til deres naboer og konkluderer, at cistercienserne integreredes i et system, »where property transactions were used not only to transfer ownership of property but also to bind people together« (197). Økonomiske, sociale og magtpolitiske motiver gjorde sig gældende sammen med de religiøse - både for det aristokrati, der gav, og for de munke, der modtog.

Det mest interessante i vor sammenhæng er naturligvis, hvis Mauss' gavegivningsteori ikke blot kan anvendes på de relationer, der etableredes mellem det gavegivende aristokrati og de kirkelige institutioner, men også på selve forholdet mellem mennesket og det transcendente. Gaverne blev jo, $\mathrm{i}$ datidens forståelse, ofte givet ikke til den og den bestemte kirkelige institu- 
tion, men til den helgen, til hvem den pågældende institution var indviet f.eks. i Clunys tilfælde til Sankt Peter. Etableredes der så også forpligtende relationer, en form for udveksling, mellem mennesker og helgener, mellem beboerne $\mathrm{i}$ den jordiske verden og deres beskyttere og forbedere $\mathrm{i}$ den himmelske?

Spørgsmålet er taget op i flere af de historiske studier, der har behandlet donationerne til kirken i middelalderen. I sin bog fra 1977 om donationerne til kirken under merovingerne, La notion de donation. Convergences: 630750 , behandler Philippe Jobert tankerne i den kristne tradition om donationen og dens værdi. De græske og latinske kirkefædre udviklede ideen om almissernes forløsende værdi og om deres effekt for tilgivelsen af synder. Almissegivning og donationer transformeredes derved fra at være en moralsk og religiøs forpligtelse til at blive en måde at opnå frelse og syndstilgivelse på. Derved blev der åbnet for en do ut des opfattelse. Donationen blev »un négoce spirituel«, en åndelig forretningsaftale, hvorved givningen af en almisse - naturligvis udført $\mathrm{i}$ den rette kristne ånd - næsten automatisk belønnes ved en guddommelig kompensation (184-185).

Med en sådan doktrin som grundlag for den middelalderlige gavegivning er man så nær Mauss, som man overhovedet kan komme. Der er etableret en udvekslingsproces mellem mennesket og det transcendente, hvorved man kan give materielle ting og modtage åndelig belønning til gengæld. Gejstligheden bliver et mellemled $\mathrm{i}$ udvekslingen, idet den modtager donationen og ved at bede for giverens sjæl medvirker til at skaffe denne belønningen $i$ det hinsides.

I sin bog Consorting with Saints. Prayer for the Dead in Early Medieval France fra 1994 kommer Megan McLaughlin ind p̊̊ denne side af sagen. I sit studie af ritualer og bønner for de døde i Frankrig mellem 750 og 1000 viser hun, at bønner for de døde var en af de modydelser, som munke og præster præsterede til gengæld for aristokratiets donationer til de religiøse institutioner. Gaver af materiel art omsattes til frelse ved gejstlig mellemkomst. $\mathrm{Og}$ det lykkedes især for munkene, som specialister $\mathrm{i}$ at bede, at etablere næsten et monopol på denne kontakt mellem de levende og de døde. Det er McLaughlins centrale tese, at der i Frankrig på denne tid skabtes et særligt mønster for bønner for de døde, der integrerede disse som medlemmer af et specifikt liturgisk samfund $i$ forhold til helgenerne. Bønnernes 


\section{Religiøs gavegivning i vesteuropæisk middelalder}

primare funktion var "to identify the dead as members of the Christian community, as friends of the clergy and as clients of the saints on earth and therefore in heaven « $(252)$.

De døde som helgenernes klienter - det sidste er vigtigt. I deres egenskab af forbedere for mennesker hos Gud udgør helgenerne selv et mellemled, og de kommer derfor også til at spille en aktiv rolle i udvekslingsprocessen mellem det jordiske og det guddommelige.

Et spørgsmål, man naturligvis må stille, er, hvorvidt de mønstre for og opfattelser vedrørende gavegivning, der er studeret for Frankrig i tidlig- og højmiddelalder, har gyldighed også for senmiddelalderen, 1300- og 1400tallet, og for andre geografiske områder. Et særligt punkt af vigtighed er, om Den sorte Død - den store pestepidemi, der omkring 1350 hærgede Vesteuropa og $\mathrm{i}$ de hårdest ramte områder dræbte op mod 40 procent af befolkningen - medførte dybtgående mentalitetsændringer med konsekvenser også for gavegivningen til kirken.

Sidstnævnte spørgsmål har Samuel K. Cohn beskæftiget sig med i to bøger om donationer og dødekult i en række italienske bystater. Netop for at kunne vurdere udviklingen og betydningen af Den sorte Død betragter han forholdene i et tidsperspektiv, der starter i 1200-tallet og går op i 1400-tallet. Helt entydige er hans resultater ikke, for der var forskel fra by til by. I det materiale, Cohn har undersøgt, først og fremmest et meget stort antal testamenter, kan der dog konstateres en generel ændring. I kølvandet på pesten ses en ændring fra mange mindre donationer til færre og større, ofte forbundet med et personligt, mindemæssigt præg som f.eks. oprettelsen af en velgørende stiftelse eller bygningen af et kapel med funktion som gravplads for en enkeltperson eller en familie. Cohn fortolker sine iagttagelser således, at indbyggerne i de italienske byer i 1200-tallet og første halvdel af 1300tallet brugte deres jordiske gods ved at give et stort antal gaver til mange forskellige kirkelige institutioner, at de spredte deres »investeringer « $\mathrm{i}$ frelsen så at sige, mens de i anden halvdel af 1300-tallet og i 1400-tallet koncentrerede dem om enkelte større donationer. Strategierne for efterlivet »the strategies of the afterlife « - var afgørende ændret.

Sammenligner man Frankrig og Burgund i tidlig- og højmiddelalder med Italien i senmiddelalderen, er der sket afgørende ændringer, hvad der selvfølgelig hænger sammen med overgangen fra et agrarsamfund, hvor donatio- 
nerne til kirken overvejende bestod af jordegods, til et bysamfund, hvor donationerne tog form af bygninger, kunstgenstande og penge. Spørgsmålet er, om der også er sket indholdsmæssige ændringer, eller om opfattelsen bag gavegivningen til kirken grundlaggende var den samme.

I en oversigt over forskningen i den middelalderlige gavegivning, som jeg har trukket kraftigt på i det foregående, har den hollandske historiker Arnoud-Jan A. Bijsterveld forsøgt at opstille de centrale problemfelter og de vigtigste uafklarede spørgsmål, at give en slags status questionis, på feltet. Hans konklusion er $\mathrm{i}$ al korthed, at gavegivningen til kirken $\mathrm{i}$ perioden mellem højmiddelalderen og senmiddelalderen i hovedsagen mistede sine politiske og sociale funktioner, men at de grundlæggende religiøse doktriner og trosforestillinger - hvis kerne var forventningen om en belønning $i$ himlen til gengæld for donationen på jorden - forblev uændrede.

Der skete afgørende ændringer fra høj- til senmiddelalder, men de bestod først og fremmest $\mathbf{i}$ ændrede donationsmønstre. De tidlig- og højmiddelalderlige donationer var knyttet til et samfund med en svag centralmagt. Det var donationer, hvor ofte meget store jordegodser af konger og adelige blev givet til kirkelige institutioner, med skabelsen af stærke politiske og sociale bånd som resultat. Fra 1100-tallet og fremefter skete en »demokratisering « af donationerne til kirken, blandt andet som følge af pengeøkonomiens fremtrængen. Fra at have været del af et næsten udelukkende aristokratisk adfærdsmønster blev givning af gaver til kirken nu noget, alle kunne være med i. Det var ikke længere de store sammenhængende godser med tilhørende privilegier og rettigheder, der blev givet, men enkelte gårde eller indtægter af sådanne, pengebeløb, naturalier, brugsgenstande osv. Samtidig skete en ændring af de mål, som donationerne rettede sig imod. Fra 1100. tallet mistede de traditionelle modtagere af fromme donationer, benediktinerklostrene, en stor del af deres tiltrakningskraft, og donationerne rettedes mod andre kirkelige institutioner, cistercienserklostrene i 1100-tallet, tiggerordnerne i 1200-tallet, siden hele senmiddelalderens brede spektrum af kirkelige institutioner og aktiviteter: domkirker og sognekirker, altre og kapeller, hospitaler og spedalskhedshuse, gilder og religiøse broderskaber osv.

En vigtig faktor af rent juridisk art i dette billede var, som Bijsterveld gør opmærksom på, testamentet, en institution fra Romerretten, der genop- 


\section{Religiøs gavegivning i vesteuropaisk middelalder}

toges i 1100-tallet og fik afgørende betydning for donationsmønstrene. Ved at gøre testamente kunne en donator i levende live give gaver til kirken, der først fik effekt efter hans død, ligesom han kunne betænke mange forskellige kirkelige institutioner på én og samme tid. Begge dele modvirkede den tidligere tendens til at skabe stærke sociale og politiske bånd mellem den gavegivende person og de gavemodtagende kirkelige institutioner. Samtidig muliggjorde testamentet, at senmiddelalderens donationer antog karakter af individuelle foretagender, hvor de i tidlig- og højmiddelalder i højere grad havde været slægtsforetagender på grund af kravet om, at slægten skulle give sit samtykke, hvis store jordegodser gik ud af dens eje ved at blive skænket til kirken. Selv hvor der fortsat var tale om store enkeltdonationer, som f.eks. i de af Cohn studerede testamentariske donationer fra tiden efter pesten, var der nu tale om individualiserede donationer, hvor den jordiske påmindelse af en bestemt person eller en bestemt familie havde fået betydelig plads ved siden af den specifikt religiøse påmindelse med henblik på at sikre sjælens frelse.

\section{II}

I en dansk middelaldersammenhæng har Mauss' gavegivningsteori ikke været inddraget før, og denne artikel prætenderer på ingen måde at levere en systematisk anvendelse af teorien på dansk middelalder. Mit formål er alene at vise, at noget sådant er muligt og relevant, hvilket jeg vil gøre ved at tage fat $i$ en enkelt central donation, der forekommer særlig velegnet hertil. Inden vil jeg dog - rent tentativt - se på, hvorledes de i den internationale forskning rejste spørgsmål generelt må besvares for Danmarks vedkommende.

Der er ingen tvivl om, at vi også i Danmark kan konstatere den grundlæggende ændring $\mathrm{i}$ donationsmønstrene, der sker fra højmiddelalder til senmiddelalder. Her møder vi også i højmiddelalderen kongelige og aristokratiske donationer af store godser til enkelte kirkelige institutioner, mens senmiddelalderen fremviser et helt anderledes mønster med mindre donationer til mange kirkelige institutioner. I den begyndende højmiddelalder var det først bispesæder og domkirker, siden benediktinernes og cisterciensernes klostre, der stod som modtagere af donationerne til kirken, og det var rigets absolutte top, konger, biskopper og højadelsslægter, der stod bag. Man kan blot nævne 1100-tallets donationer til oprettelsen af klostre: Hvideslægtens 
Sorø, ærkebiskop Eskils Esrom, kong Valdemar den Stores Vitskøl osv. (Ulsig, 229-231). I senmiddelalderen gik donationerne til tidens nye klosterordner, efterhånden som de dukkede op her i landet, først de to tiggerordner i 1200-tallet, siden f.eks. birgittinerne i 1400-tallet. Den mest karakteristiske form for donation til kirken var dog oprettelsen af kapeller og altre, hvortil knyttedes indstiftelsen af gudstjenester, sjælemesser, anniversarier osv. I forhold til højmiddelalderens højaristokratiske donationer var senmiddelalderens tilgængelige for en betydeligt bredere kreds: almindelige sognepræster, lavadelsmænd, borgere, ja selv bønder kunne være med - om ikke andet så hvis de forenede sig i et af tidens mange gilder, der næsten alle stod for egne gudstjenesteindstiftelser (Ingesman 1993, 153).

Mere uafklaret er det, om vi også i Danmark ser en modifikation i det senmiddelalderlige donationsmønster som følge af Den sorte Død omkring 1350 i stil med den ændring, som Samuel K. Cohn har konstateret for Italiens vedkommende. Det synes dog klart på nuværende tidspunkt, at selv om de mange små testamentariske donationer stadig repræsenterede det dominerende billede $\mathrm{i}$ tiden mellem pesten og reformationen, så finder vi faktisk eksempler på den type donationer med en individuel eller familiemassig mindefunktion, som Cohn har noteret sig som et nyt element $i$ Italien. Christian I's Helligtrekongers kapel i Roskilde domkirke, forskellige adelige familiekapeller og visse biskoppelige kapeller kan nævnes som de mest oplagte eksempler. Den stiftelse, jeg skal se nærmere på i det følgende, er måske nok det mest markante, men på ingen måde det eneste eksempel på en stor individualiseret enkeltdonation med stærke træk af mindefunktion.

Hvad angår spørgsmålet om de grundlæggende religiøse doktriner og trosforestillinger bag donationerne til kirken i dansk middelalder, så er det et nærmest helt ubehandlet spørgsmål - i hvert fald et spørgsmål, der ikke har været genstand for nogen mere detaljeret undersøgelse. Lars Bisgaard har været inde på adelens fromhedsidealer $\mathrm{i}$ senmiddelalderen og har $\mathrm{i}$ den forbindelse fremhæuet nogle af de tanker, der kommer eksplicit til udtryk i alterstiftelser og testamenter. Hovedsynspunktet viser sig at være, at man ved at give gaver til kirken og til de fattige kan bruge sit jordiske gods - som man alligevel ikke kan tage med sig, når man forlader denne verden - på en måde, så ens sjæl trods alt făr gavn af det efter døden, at man kan »omskifte denne verdens forfæengelige gods til det som evigt bliver«, som en skånsk 


\section{Religiøs gavegivning i vesteuropæisk middelalder}

lavadelsdame udtrykker det i 1481 (Bisgaard, 70). ${ }^{2}$ Det adskiller sig, som man vil se, ikke fra, hvad vi finder $i$ udlandet - eller for den sags skyld $i$ tilsvarende dokumenter fra danske gejstlige. I en Lundekanniks testamente fra 1505 gives direkte et skriftbelæg for opfattelsen $\mathrm{i}$ form af en henvisning til Lukasevangeliets - åbenbart meget bogstaveligt forståede - ord i lignelsen om den utro godsforvalter: „Skaf jer venner ved hjælp af den uretfærdige mammon, for at de, når det er forbi med den, kan tage imod jer $i$ de evige boliger« (16,9; Ingesman 1993, 142f).

\section{III}

Resten af artiklen kommer til at dreje sig om ærkebisp Birger Gunnersens gudstjenestestiftelse i krypten under domkirken i Lund. ${ }^{3}$ Den er berømt som den sidste og største af sin art $\mathrm{i}$ dansk senmiddelalder. Antallet af fæestegårde, der blev givet til gudstjenestestiftelsen, nærmede sig 90. De Mariatider, messer, vigilier og anniversarier, der dagligt skulle synges og læses $i$ forbindelse med stiftelsen, krævede hele tre præster assisteret af to degne og to kordrenge. Og tallet på personer, for hvis sjæle der med navns næunelse skulle bedes under gudstjenesterne, androg mere end 100. Graden af mindefunktion knyttet til denne stiftelse - klart et eksempel på den store enkeltdonation - er det ene spørgsmål, der skal interessere os i det følgende.

Birger Gunnersens gudstjenestestiftelse er ikke kun berømt på grund af sin størrelse. Fundatsen for stiftelsen er et omfangsrigt dokument, som ud over et væld af informationer om senmiddelalderlig liturgi og religiøsitet giver et enestående indblik i ærkebispens verden og mentalitet. Langt mere eksplicit end de af Lars Bisgaard studerede adelige testamenter og messestiftelser formulerer Birger Gunnersens fundats tanker omkring det at give gaver med henblik på sjælens frelse. Jeg skal bruge den til belysning af det andet spørgsmål, der optager os her, spørgsmålet om de grundlæggende ideer bag donationerne til kirken.

Hverken gudstjenestestiftelsen eller den bagvedliggende religiøse opfattelse kan man forstå uden at kende noget til Birger Gunnersens personlige baggrund. Vi skal derfor tage vort udgangspunkt i manden og derfra gradvis nærme os hans gudstjenestestiftelse og dens fundats.

Takket være det store stiftelsesdokument er Birger Gunnersen en af de gejstlige $\mathrm{i}$ dansk senmiddelalder, om hvis liv og karriere vi er bedst orien- 
teret. I sin gudstjenestestiftelse ønsker ærkebispen, at der skal bedes for alle, som på en eller anden måde har hjulpet ham i løbet af hans liv. Det er ved sin omhyggelige opregning af alle disse velyndere og deres gode gerninger, at vort dokument bliver en fremragende kilde til Birger Gunnersens liv og karriere, næsten lige så meget en selvbiografi som et stiftelsesbrev. ${ }^{4}$

Birger Gunnersen blev født omkring 1445, måske et par år tidligere, som søn af degnen i Lindebjerg sogn i Himle herred i Halland. Han gik i skole $\mathrm{i}$ den nærmeste købstad, Varberg, formodentlig $\mathrm{i}$ begyndelsen af 1450 'erne. Ved midten af 1450 'erne fortsatte han til katedralskolen, ikke den i hans eget stift, Lund, ganske vist, men derimod katedralskolen i Roskilde. Og endelig gik han i skole uden for Danmark, i den ansete katedralskole i Skara i Sverige, hvor han tilbragte fem år. Det må have været omkring 1460, og dermed var han forberedt til at påbegynde studier ved universitetet $i$ Greifswald i maj 1464. På fire år tog han sin magistergrad, og i 1469 optræder han selv som lærer ved universitetet.

Blandt sine velyndere nævner Birger fire familier, som gav ham herberg i hans skole- og universitetstid: en i Varberg, en i Roskilde, en i Skara og en i Greifswald. De kan have gjort det for betaling, men nok så sandsynligt er det, at det at optage en fattig pebling i sit hus simpelthen er blevet betragtet som en form for almissegivning. Som velyndere i Skara nævner Birger endvidere to biskopper. Hermed făr vi det første eksempel på, at Birger bliver hjulpet frem af højtstående kirkemænd; men absolut ikke det eneste, for hele Birgers karriere efter hjemkomsten fra Greifswald var i virkeligheden bestemt af højerestående personers promovering af ham: Ærkedegnen i Lund kaldte ham - omkring 1470 - hjem fra universitetet for at blive leder af katedralskolen i Lund; kongens kansler kaldte ham i 1474 fra Lund til det kongelige kancelli for at blive skriver her; og kongen selv gjorde ham i 1477 til kansler for sin dronning, Dorothea.

Dermed var Birgers lykke gjort, for gejstlige i kongefamiliens tjeneste blev rigt belønnet med de sognekirker, kanonikater, prælaturer og i sidste ende bispeembeder, som kongen forstod at skaffe sine betroede mænd. I sit stiftelsesdokument nævner Birger tildelingen af gejstlige embeder ved siden af de mange andre velgerninger, han nød af kong Christian I og hans dronning: »de os stor ære og dyd gjorde, og forsynede os med beneficier og prælaturer, og os elskede og meget til gode gjorde i mange måder; for 


\section{Religiøs gavegivning i vesteuropæisk middelalder}

hvilket Gud og Jomfru Maria deres nåders sjæle lønne og give dem den evige himmeriges glæde og fryd derfor foruden al ende « (Suhm, 22).

Birger Gunnersen var kansler for dronning Dorothea indtil hendes død i 1495, og umiddelbart efter blev han af kong Hans gjort til kansler for dennes dronning, Christine. Kort efter, i 1497, kom forfremmelsen til ærkebiskop i Lund. Netop på dette punkt er Birgers fundats omhyggelig med at understrege, at han - i overensstemmelse med den kanoniske rets regler - blev valgt af domkapitlet til embedet. Vi ved dog nok om de politiske realiteter i senmiddelalderens Danmark til at være sikre på, at dette var en ren formalitet; det var i den slags tilfælde altid kongens ønsker, der afgjorde sagen. Forfremmelsen af Birger Gunnersen til ærkebiskop i Lund i 1497 var da den sluttelige belønning for mere end tyve års tro tjeneste for den danske kongemagt.

Med udnævnelsen til ærkebiskop havde degnesønnen foretaget en social opstigning bogstavelig talt fra bunden til toppen af datidens danske samfund. Birger Gunnersen var nu ikke blot den danske kirkes og de danske biskoppers leder, i realiteten var han den højst rangerende mand i riget efter kongen selv. Det kom til udtryk ved, at han førte forsædet i rigsrådet, den forsamling af de danske biskopper, abbederne fra de største klostre samt de vigtigste adelsmænd, der i fællesskab med kongen var ansvarlig for rigets styre.

Udnævnelsen af Birger Gunnersen til ærkebiskop kom som et chok for den danske adel. Hurtigt udbrød en voldsom strid mellem den nye ærkebiskop og en skånsk adelsfaktion med den mægtige rigshofmester Poul Laxmand i front. Den udviklede sig til et veritabelt politisk trekantsdrama med kongen, ærkebispen og rigshofmesteren i hovedrollerne og endte først, da Poul Laxmand i 1502 blev stukket ned midt i København, hvorefter han posthumt dømtes som forræder og alt hans gods tilkendtes kronen (Bruun, 43-134). Vigtigt at gøre opmærksom på i vor sammenhæng er imidlertid, at kampen mellem Birger Gunnersen og hans adelige modstandere ikke kun var en politisk magtkamp. Den repræsenterede et sammenstød mellem en adelig og en gejstlig standsbevidsthed og selvfølelse - og blev derfor også en kamp på de symboler, hvorigennem standsbevidsthed og selvfølelse manifesteredes. I den sammenhæng kommer ærkebispens gudstjenestestiftelse og kulten omkring hans gravsted ind $\mathrm{i}$ billedet. 
Som det absolutte centrum i koret i kryptkirken i Lund, hvor Birger Gunnersens gudstjenestestiftelse skulle have hjemme, står den dag i dag ærkebispens imponerende gravmæle, et kunstnerisk mesterværk skabt af den berømte stenhugger Adam van Düren. På gravmonumentet ligger ærkebispen i fuld figur i sit bispeskrud, for enden sidder det våbenskjold med et lindetræ, som vi også kender fra Birger Gunnersens segl. Om netop dette våbenskjold har vi overleveret en anekdote i den efterreformatoriske Lundebisp Mogens Madsens fremstilling af de middelalderlige ærkebispers historie. Det fortælles her, at den højadelige ridder og rigsråd Henrik Krummedige, hvis slægt netop har en lind som sit våbenmærke, i rigsrådets nærværelse klagede over, at ærkebispen - skønt ikke adelig og »næsten en bondes søn« - førte samme våben. Birger Gunnersen står da op og holder en lang tale. Han erkender sin ringe byrd, og at han kun har nået sin høje stilling i kraft af kongens og dronningens gunst. Han under vel adelen dens højhed og ære og vil aldeles ikke bruge dens våben. Hans lind har imidlertid intet med Krummedigernes lind eller med andre adelsslægters træer at gøre. Den er et mærke (symbolus), ikke et våben. Derpå giver han en lang allegorisk udlægning af mærket og dets enkelte dele: Linden kommer af, at han er født i Lindebjerg sogn. Den tredobbelte rod, der forenes i én stamme, betegner den hellige trefoldighed. De fem grene og lige så mange roser er Kristi fem sår. De ti blade er de ti bud. De syv sten, der ligger under linden, betegner de syv dødssynder. Himlen over linden betegner, at hans fødested ligger i Himle herred, men skal samtidig minde om det himmelske fædreland. Og med denne tale, der slutter med en opfordring til Henrik Krummedige om derefter at fortælle, hvad hans lind betyder, lukker ærkebispen eftertrykkeligt munden på sin modstander (Madsen, 221-225).

Historien er sent overleveret og vel ikke nødvendigvis pålidelig i alle detaljer. Rigtigt er imidlertid, at våbenskjoldet, adelssymbolet par excellence, udøvede en betydelig tiltrækningskraft på den højere gejstlighed i dansk senmiddelalder. Jeg har andetsteds fremdraget adskillige eksempler på, at højgejstlige, der beviseligt ikke var af adelig herkomst, alligevel benyttede våbenskjolde $\mathrm{i}$ deres segl - utvivlsomt for at markere deres ligestilling med den adel, som de socialt og statusmæessigt var på niveau med, ja i egen selvforståelse ligefrem højere placeret end (Ingesman 1987). Birger Gunnersens annektion af det adelige symbol er imidlertid betydeligt mere raffineret, 


\section{Religiøs gavegivning i vesteuropzeisk middelalder}

end Mogens Madsens historie lader ane. Både på sarkofagen og i seglafbildningerne er våbenskjoldet med lindetræet omgivet af en række magt- og værdighedssymboler, eksempelvis primatskorset symboliserende de lundensiske ærkebispers primat over den svenske kirke. Hele symbolikken fortjener en nærmere analyse, men jeg skal nøjes med at fremdrage en enkelt detalje: Som normalt på adelige segl er der over skjoldet anbragt en ridderhjelm, men oven $p d$ denne igen sidder en bispehat! Bispehat og ridderhjelm - enkle og umisforståelige symboler, hvormed Birger giver udtryk for, at biskoppens åndelige magt er overordnet ridderens verdslige magt, at gejstligheden er højere rangerende end adelen.

\section{IV}

Birger Gunnersens gudstjenestestiftelse skulle afvikles omkring ærkebispens gravmonument i domkirkens krypt, men den var også i sig selv en slags monument. Til evig tid - det var tanken - skulle hver eneste dag, år ud og år ind, afholdes gudstjenester i krypten, hvorunder præster skulle læse messer og bede forbønner med nævnelse af Birgers navn. Og som en anden farao havde ærkebispen indledt arbejdet med dette mindesmærke over sig selv allerede i starten af sin embedsperiode, ja på en måde længe før.

I sit stiftelsesdokument fortæller Birger, at han som ung klerk $\mathrm{i}$ et skriftemål fik pålagt at læese Jomfru Marias tider hver lørdag, men desværre var forsømmelig med at opfylde pålægget. Sin forsømmelse søgte han senere at råde bod på ved at indstifte en gudstjeneste til Jomfru Marias ære. Ret tidligt i sin karriere, mens han som dronning Dorotheas kansler var sognepræst i dronningens residensby Kalundborg, stiftede han i byens store Vor Frue kirke en daglig sungen gudstjeneste til den hellige jomfrus are. $\mathrm{Og}$ da han i 1497 blev ærkebiskop, tog han ganske enkelt denne stiftelse med sig til Lund (Weibull, 280).

Med den beskedne gudstjenestestiftelse fra Kalundborg som kerne opbyggedes nu gradvis Birgers store stiftelse i Lund. Allerede i 1499 gav en væbner fra Falster sin godkendelse af, at en gård, han havde skænket til Birgers Mariatjeneste i Kalundborg, i stedet måtte komme den nye stiftelse i Lund til gode. Samme år skænkede en af ærkesædets lavadelige klienter hele sit gods, bestående af en hovedgård og en snes fæestegårde, til opretholdelse af en daglig sungen messe til Jomfru Marias ære og alle Vor Frues daglige 
tider i Lunds domkirke. I 1503 fulgte kong Hans efter ved at give Poul Laxmands store hovedgård Åkarp i nærheden af Lund til afholdelse af en »evig messe fra ærkebispen selv. Oprindelig ejede Birger, med sin beskedne sociale baggrund, naturligvis ikke eget gods; men gennem hele sin karriere havde han forstået at lægge fra og omsætte pengeindtægter i jordegods, uden tvivl netop med henblik på engang at donere godset til kirken. Blandt det gods, han nu erhvervede til sin gudstjenestestiftelse, var dels en større mængde af Poul Laxmands konfiskerede gods, som han havde købt af kongen, dels et antal enkeltgårde, som stammede fra mere eller mindre fallerede lavadelsmænd. Gennem disse store donationer og flere mindre fra diverse præster og lavadelsfolk med tilknytning til domkirken og ærkesædet samlede ærkebispen efterhånden en kolossal godsmængde til sin gudstjenestestiftelse (Weibull, 280-286).

Godsdonationer var en forudsæetning for etableringen af den slags »evig« gudstjeneste, der var tale om her; det var afkastet af de mange fæstegårde og enkelte købstadsejendomme, der i al fremtid skulle betale for de medvirkende præster, degne og kordrenge. Men Birger havde to andre bekymringer ud over fremskaffelsen af det nødvendige jordegods: tilvejebringelsen af passende fysiske rammer omkring gudstjenestestiftelsen og udformningen af en fundats, der i detaljer fastlagde stiftelsens ordning.

Med hensyn til det første må vi gå ud fra, at udgangspunktet for Birgers overvejelser har været, at stedet for gudstjenesternes afvikling skulle være identisk med stedet for ærkebispens fremtidige gravplads. Derved bliver det af betydning at undersøge, hvorledes Birger Gunnersens forgangere havde valgt deres gravsteder og indrettet de dertil knyttede gudstjenestestiftelser, eller med andre ord, hvorledes Birger forholdt sig til eventuelle foreliggende traditioner for ærkebiskoppelige begravelser i Lund.

Jeg har andetsteds påvist, at et kapel, som i 1420'erne opførtes på sydsiden af domkirken i Lund, udviklede sig til et egentligt ærkebiskoppeligt gravkapel, idet både bygherren selv, ærkebisp Peder Lykke (1418-36), og hans tre efterfølgere, Hans Laxmand (1436-43), Tue Nielsen (1443-72) og Jens Brostrup (1472-97), lod sig begrave i dette kapel. Alle fire ærkebisper betænkte da også kapellet med større eller mindre godsgaver. Peder Lykke selv lagde grunden ved at give to gårde i Landskrona, to gårde i København, 


\section{Religiøs gavegivning i vesteuropaisk middelalder}

fire fæestegårde samt noget af sit fædrenegods på Sjælland til kapellet. Hans Laxmand må også have betænkt det, siden hans store gudstjenestestiftelse indbefattede læsning af daglige messer ved hovedalteret $\mathrm{i}$ kapellet. Tue Nielsen skænkede i sit testamente et større pengebeløb til kapellet - foruden at hans broder, som var dekan ved domkapitlet, funderede et alter i kapellet. Endelig stiftede også Jens Brostrup, i 1488, et alter i kapellet (Ingesman 1988, 260f).

I løbet af 1400-tallet var der således skabt en tradition for de ærkebiskoppelige begravelser. Den tradition brød Birger Gunnersen med. Det kan der have været tvingende grunde til, som f.eks. at der ikke var plads til endnu et ærkebiskoppeligt gravmæle i kapellet; men det ligger nu mere på linie med vor viden $\mathrm{i} \emptyset \mathrm{vrigt}$ om Birger og hans gudstjenestestiftelse at opfatte bruddet som en helt bevidst handling: Birger Gunnersen ville have en stiftelse, der var hans egen, en stiftelse, der ikke nøjedes med at indrangere ham som én i rækken af senmiddelalderlige ærkebiskopper, men tværtimod hævede ham frem som noget helt specielt.

Den første beskedne Mariatjeneste, som den nyudnævnte ærkebiskop indrettede i Lund, holdtes i kryptkirken under domkirken. Her var forholdene dog ikke ideelle, blandt andet fordi der ofte stod så meget vand på gulvet, at afholdelsen af gudstjenesterne besværliggjordes. Det blev da også snart ærkebispens plan at opføre et nyt kapel på domkirkens nordside, hvor der stadig var plads hertil. Endnu i 1506 nævner et lokalt testamente "Vor Frues kapel «, som ærkebispen agter at bygge; men i årene derefter blev denne plan opgivet. I sit stiftelsesdokument fortæller ærkebisp Birger, at det var kong Hans, der under et besøg i Lund overtalte ham til at opgive at bygge et nyt kapel og i stedet lade den gamle kryptkirke sæette $\mathrm{i}$ stand. Med Adam van Düren som bygmester gennemførtes derpå et omfattende restaurerings- og ombygningsarbejde, der indbefattede en dræning af krypten og en genetablering af kapellerne i nord og syd. Ud over arkebispens sarkofag, der var færdig i 1512, skabte Adam van Düren her i krypten et andet bekendt værk, den med mærkelige satiriske billeder udsmykkede brøndkarm, der bærer årstallet 1514. Mest gjordes imidlertid ud af koret i kryptkirken, der var tænkt som det egentlige centrum i ærkebispens gudstjenestestiftelse. Det afspærredes ved en skranke fra den $\emptyset$ vrige kirke, der opsattes korstole langs siderne, højalteret ombyggedes, og præcis under midterhvælvet anbragtes så 
- som det naturlige midtpunkt - ærkebispens monumentale sarkofag (Weibull, 286f).

Den store gudstjenestestiftelse var i virkeligheden sammensat af fem forskellige dele, og den involverede ikke kun krypten, men inddrog også andre dele af domkirken. I alle detaljer at referere det omfattende liturgiske program, der skulle afvikles i forbindelse med stiftelsen, er ikke muligt, men heller ikke nødvendigt her, hvor vi først og fremmest interesserer os for den til stiftelsen knyttede mindefunktion.

Den ene del af gudstjenestestiftelsen var selve den daglige læsning af Jomfru Marias tider, som skulle finde sted i de to kapeller i kryptkirken, i hvert af dem ved en præst med hjælp fra en degn og en kordreng. Om morgenen startede den med ottesang og kulminerede i en messelæsning med fem kollekter, idet kollekterne skiftede hver dag igennem en to ugers cyklus. Derefter var der en pause i gudstjenesterne, hvor dørene til krypten atter lukkedes, og lysene slukkedes. Først ved tiden for aftensangen begyndte gudstjenesten igen. Oven p§̊ aftensangen fulgte natsangen, og effektfuldt sluttede dagens program med, at begge præster ledsaget af deres degne og kordrenge vandrede til ærkebispens grav i kryptens kor, hvor der påny holdtes gudstjeneste. Enten efter messen eller efter aftensangen, som det var mest bekvemt for præsterne, var der vigilier med ni lektier og tre kollekter, her med forskellige kollekter for hver dag i en ugentlig cyklus (Weibull, 289).

Den anden del af ærkebispens gudstjenestestiftelse var læsningen af sjælemesser, der skulle varetages af den tredje præst tilknyttet gudstjenestestiftelsen. På samme tid som Mariatiderne læstes i nord- og sydkapellet i krypten, skulle han for højalteret $i$ koret læse en evig sjælemesse. Dertil skulle han, på et tidspunkt efter eget valg, hver dag læse en vigilie for ærkebispens sjæl og for sjælene af de mange andre personer, der var næunt $\mathrm{i}$ gudstjenestens fundats (Weibull, 290).

Tredje, fjerde og femte del af Birgers gudstjenestestiftelse var $i$ hovedsagen pålagt domkapitlets medlemmer. Når domkirkens prælater og kanniker på søn- og højtidsdage i procession vandrede ned i krypten for at holde en såkaldt statio ved højalteret her, skulle de også synge en antifon over Birgers grav. En kannik skulle hver dag synge højmessen for højalteret oppe i domkirken, idet han bad til Gud for ærkebispen og dennes forgængere og 


\section{Religiøs gavegivning i vesteuropaisk middelalder}

efterfølgere. Og endelig skulle der til evig tid synges fire anniversarier, årlige mindegudstjenester, ved Birgers grav. De to af dem skulle foreg̊̊ tirsdag og onsdag efter dominica Letare (midfaste søndag) og skulle personligt ledes af den til enhver tid værende ærkebiskop i Lund, mens domkirkens kantor skulle lede de to andre, der skulle ligge på Sankt Lucias dag og dagen derefter (13. og 14. december); i alle tilfælde forventedes prælater, kanniker og øvrigt præsteskab ved domkirken at vandre $\mathrm{i}$ procession ned $\mathrm{i}$ krypten for at overvære dem (Weibull, 290f).

Vi kan nu konkludere på spørgsmålet om graden af mindefunktion i forbindelse med ærkebisp Birger Gunnersens gudstjenestestiftelse. Om denne har Henry Bruun udtalt, at der ikke kan være nogen som helst tvivl om dens mål: »det var at gøre Lunds domkirke til en helgendyrkelsens og forbønnens højborg i Norden« - idet han dog samtidig indrømmer, at den fuldt realiseret »også måtte sikre sin ophavsmand en slags jordisk udødelighed, som næppe var ham imod« (Bruun, 136). Denne konklusion rammer efter min mening ikke det centrale. Ærkebisp Birgers store gudstjenestestiftelse var en omfattende og kompleks stiftelse, der utvivlsomt havde ikke blot ét, men flere mål. Ét af dem - og et meget vigtigt af dem - var imidlertid at sætte et evigt monument over ærkebispen, og derfor var der tale om en stiftelse, som fra fø̣rst til sidst havde Birger selv i centrum, og som således fremviser præcis det element af individcentreret mindefunktion, Samuel K. Cohn har beskrevet for renæssancens Italien. Et andet mål var at give en storslået manifestation af gejstlig standsbevidsthed og selvfølelse i form af en stiftelse, der overgik alle tilsvarende fra adelig side og i realiteten nærmede sig det fyrstelige niveau. Med sin bevidste brug af arkitektoniske, kunstneriske og liturgiske virkemidler bragte Birger Gunnersens gudstjenestestiftelse i kryptkirken i Lund p̊̊ raffineret vis de sociale og politiske overtoner til at klinge sammen med de personlige og religiøse.

V

Valget af domkirkens krypt som hjemsted for gudstjenestestiftelsen og den påbegyndte istandsættelse og nyindretning af kryptrummet til formålet løste problemet med at tilvejebringe de fysiske rammer omkring Birger Gunnersens stiftelse. Der resterede at formulere en fundats, som ordnede alle forhold vedrørende stiftelsen på en måde, så ærkebispen kunne være fuldstæn- 
dig sikker på, at den virkelig ville komme til at fortsæette til evig tid. Ved stiftelsen af en evig gudstjeneste skulle tre væsentlige forhold fastlægges på en retsligt holdbar facon: hvilket gods der skulle tillægges gudstjenestestiftelsen, hvem der skulle have ret til at administrere godset og indsætte de præster der skulle forrette gudstjenesterne, samt hvilke messelæsninger og andre liturgiske handlinger der skulle præsteres af de pågældende præster (Ingesman 1993, 153). Dette skete i "Sanctuarium Birgerianum«, som fundatsen for Birgers stiftelse normalt kaldes. Vi har allerede hørt om det til gudstjenestestiftelsen henlagte gods og om stiftelsens omfattende liturgiske program; administrationen af godset og indsættelsen af præsterne, der $\mathrm{i}$ hovedsagen pålagdes Birgers efterfølgere som ærkebiskopper $i$ Lund, er derimod et punkt, jeg helt må lade ligge. Jeg vender mig nu til vort andet spørgsmål: hvad »Sanctuarium Birgerianum« fortæller om de grundlæggende religiøse ideer bag Birgers stiftelse.

»Sanctuarium Birgerianum« er dateret den 18. december 1518, men som Lauritz Weibull har påvist, må fundatsen for hoveddelens vedkommende være skrevet i 1512 (Weibull, 276f). Ærkebispen har altså udformet den på samme tid, som hans bygmester arbejdede med at skabe de rette fysiske rammer om stiftelsen nede i krypten. Ligesom gudstjenestestiftelsen som sådan overgik »Sanctuarium Birgerianum« alt, hvad man hidtil havde set inden for genren. Formelt er fundatsen et dokument, reelt er det en hel bog, vi har for os: et pragtfuldt udstyret pergamentshåndskrift på knap 150 sider. Fundatsen udfærdigedes $i$ to eksemplarer, forsynedes med Birger Gunnersens egenhændige underskrift og blev, til ydermere sikring af overholdelsen, stadfæstet af en pavelig legat, der da opholdt sig i Danmark, Johannes Angelo Arcimbold. Det skete den 1. april 1519, trekvart år før ærkebispen for sidste gang lukkede sine øjne (Weibull, 276).

I min ovenfor givne skildring af Birger Gunnersens personlige baggrund og livsforløb har jeg benyttet den del af »Sanctuarium Birgerianum«, der forordner læsning af sjælemesser for alle, der på en eller anden måde havde hjulpet ærkebispen på hans livsvej. Denne del af fundatsen fortæller imidlertid ikke blot, hvem der havde begunstiget Birger Gunnersen og på hvilken måde. Den viser ogs̊̊, først og fremmest ved den rakkefølge, hvori den opregner begivenheder og personer, noget om, hvordan ærkebispens verdensbillede var struktureret. 


\section{Religiøs gavegivning i vesteuropæisk middelalder}

Det er karakteristisk for Birger Gunnersens verdensbillede, at det opererer med opdelinger mellem forskellige sfærer og med hierarkisk strukturering mellem og inden for de enkelte sfærer. De to fundamentale opdelinger er mellem himmel og jord og mellem gejstligt og verdsligt. Og ligesom himlen er over jorden, og gejstlige personer rangerer over verdslige personer, så finder vi inden for hver enkelt sfære en hierarkisk struktureret ordning. I himlen har man det himmelske hierarki: Gud, Jomfru Maria og helgenerne. Inden for den gejstlige sfære finder man kirkens hierarki: paven, kardinalerne, patriarkerne, ærkebisperne, biskopperne, prælaterne og så videre nedad. Og inden for den verdslige sfære har man samfundets basale sociale strukturering: fyrster, riddere, væbnere, borgere, bønder, ned til afhængig arbejdskraft $\mathrm{i}$ bunden. Ja, selv inden for samfundets mindste enhed, familien, finder vi en hierarkisk struktur: far, mor, sønner, døtre, tjenere.

Af den hierarkiske struktur følger, at relationer mellem enkeltindivider tenderer mod at være vertikale og ulige. De bliver relationer, der oplagt kan beskrives under anvendelse af terminologien fra Mauss: relationer, hvor en form for udveksling finder sted mellem to parter, og hvor der derfor etableres forpligtelsesbånd mellem dem. I Birgers fundats ses to slags forpligtelsesbånd i funktion - og det er vigtigt at huske på, at dette galder både for relationer mellem mennesker her på jorden og for relationer mellem de jordiske og de himmelske vasener. Den første slags forpligtelsesbånd etableres derved, at en gave gives af en højerestående til en laverestående, hvorved sidstnæunte kommer i taknemmelighedsgæld og bliver forpligtet til at yde gengaeld eller tilbagebetale gaven på en eller anden måde. Den anden slags forpligtelsesbånd fremkommer, når en laverestående præsterer en form for tjeneste til en højerestående, der så bliver forpligtet til at give en passende belønning herfor (se fig. 1).

Disse grundlæggende relationer er helt centrale for forståelsen af Birger Gunnersens gudstjenestestiftelse. Når Birger i sin stiftelse etablerer sjælemesselæsning for alle sine velyndere gennem tiden, hænger det netop sammen med, at han føler sig forpligtet til at tilbagebetale, hvad han er blevet givet af de pågældende. Derfor har vi her et tredje vigtigt formål med Birgers gudstjenestestiftelse: Ved at indstifte messelæsning for sjælene af sine benefactores tilbagebetaler Birger - nu hvor han er i stand til det - de 

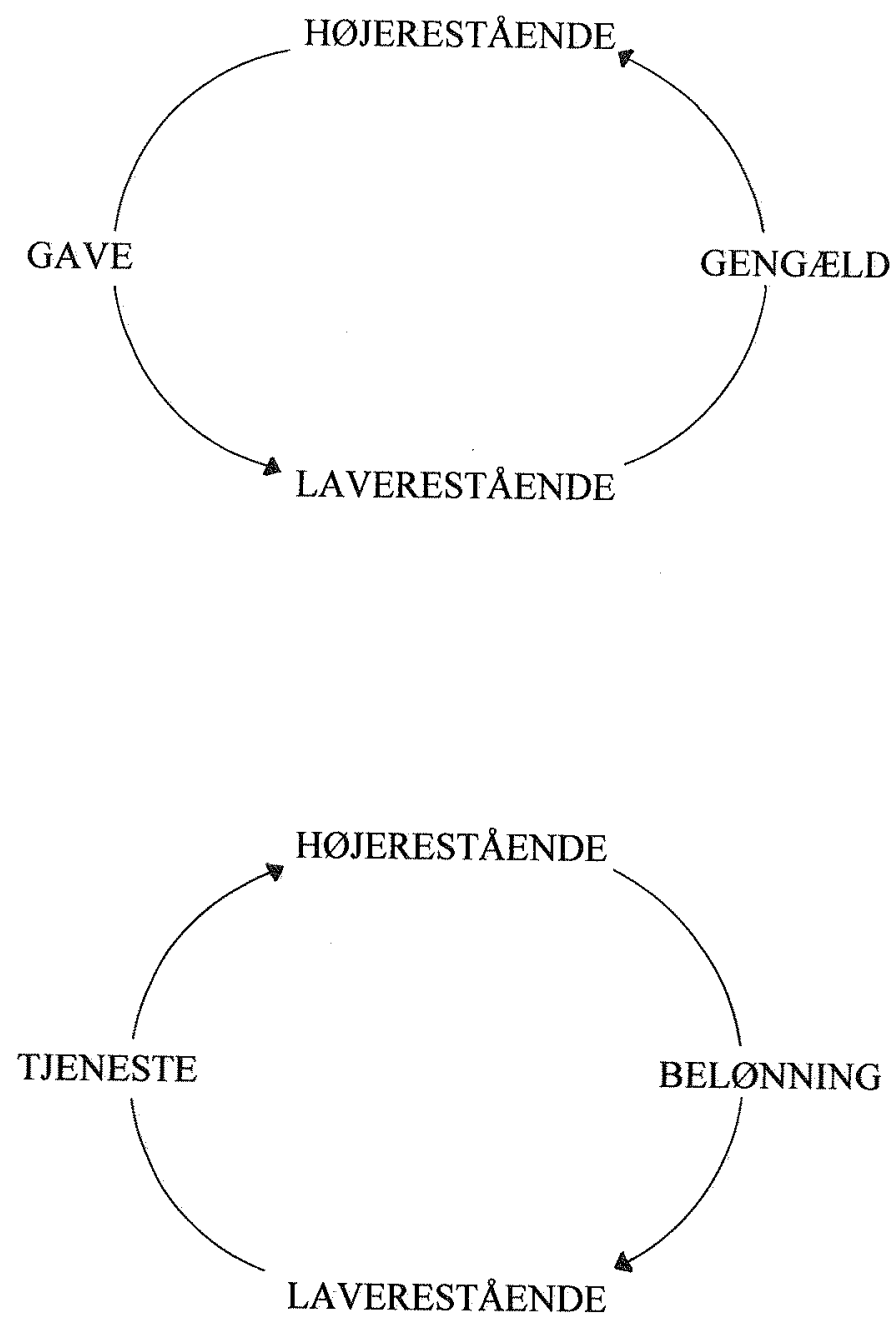

Fig. 1. 


\section{Religiøs gavegivning i vesteuropæeisk middelalder}

mennesker, som har bedt for ham, givet ham herberg og almisser, gjort ham godt $i$ ord eller handling.

Mens det $i$ forholdet mellem Birger og hans velyndere er det førstnæunte af de to slags forpligtelsesbånd, der lægges mest vægt på: det at en givet gave skal gengældes, er det $\mathrm{i}$ forholdet mellem Gud og menneske den anden slags: at tjeneste ydet en højerestående făr en passende belønning. "Sanctuarium Birgerianum « kender to former for tjeneste over for Gud og hans himmelske hærskare: dels den egentlige gudstjeneste - ordet er ikke tilfældigt og dels gode gerninger. Gudstjeneste er, hvad Birger Gunnersen til overmål tilvejebringer i sin stiftelse, idet han regner med at blive belønnet derfor på behørig vis. Gode gerninger er handlinger, som man gør mod sine medmennesker, men som Gud giver belønningen for. Og det understreges flere gange, at hvis nogen har gjort noget godt mod Birger, så er der tale om en god gerning, som Gud vil belønne den pågældendes sjæl for i himlen. "Sanctuarium Birgerianum« formulerer dette helt eksplicit i nogle afsluttende bemærkninger, hvor Birger Gunnersens efterfølgere som ærkebiskopper tillige med medlemmerne af domkapitlet i Lund formanes til at sørge for, at den indstiftede gudstjenestestiftelse opretholdes $\mathrm{i}$ al fremtid: De kan være sikre på at blive belønnet herfor - »at fange der god løn for «, som det udtrykkes - af Gud, Jomfru Maria, Sankt Laurentius og alle Guds helgener, »som ingen gode gerninger lader være ulønnede $\ll$ (Suhm, 71f).

Vi kan nu konkludere på spørgsmålet om de grundlæggende religiøse ideer bag Birgers stiftelse. Birger Gunnersens syn på relationerne mellem mennesket og den himmelske hærskare kan i virkeligheden beskrives som et forhold mellem en patron og hans klient eller mellem en herre og hans tjener. I den henseende kan man sige, at Birgers verdensbillede afspejlede de sociale realiteter, han havde erfaret i sit eget liv, hvor benefactores og patroner havde hjulpet ham og muliggjort hans enestående sociale opstigen. I det grundlæggende synspunkt adskiller Birgers opfattelse sig dog ikke fra den gængse, som vi kender både fra udlandet og fra den danske adels stiftelser. Det er Birgers faste overbevisning, at ligesom en herre belønner sin tjener og en patron sin klient, således vil gode gerninger mod ens medmennesker og indstiftelsen af gudstjenester til ære for Gud, Jomfru Maria og helgenerne få sin sikre belønning $\mathrm{i}$ himlen $\mathrm{i}$ form af evig glæde og fryd for sjælen. Saledes 
bliver der også hos Birger tale om en udvekslingsproces, hvor man kan give gaver på jorden og få løn i himmerige.

VI

Med udgangspunkt i spørgsmål rejst i international forskning har jeg undersøgt ærkebisp Birger Gunnersens senmiddelalderlige gudstjenestestiftelse i kryptkirken i Lund, idet jeg har fokuseret på to aspekter: graden af mindefunktion knyttet til stiftelsen og de religiøse ideer bag den. Jeg skal ikke gentage de konklusioner vedrørende hvert af de to aspekter, der allerede er formuleret ovenfor, kun ridse enkelte linier op til afslutning.

Interessen for eventuelle mindefunktioner $\mathrm{i}$ forbindelse med den lundensiske stiftelse udspringer af det bredere spørgsmål om ændringerne i donationsmønstrene gennem middelalderen og baggrunden herfor. De tidlig- og højmiddelalderlige donationer var donationer, hvor ofte meget store jordegodser af konger og adelige blev givet til enkelte kirkelige institutioner, typisk de store benediktiner- og cistercienserklostre, hvorved der skabtes stærke politiske og sociale bånd. Fra 1100-tallet og fremefter skete en »demokratisering « af donationerne til kirken, således at donationerne ikke længere bestod af store sammenhængende godser med tilhørende privilegier og rettigheder, men af enkelte gårde eller indtægter af sådanne, pengebeløb, naturalier, brugsgenstande osv., ligesom modtagerne af donationerne ændredes fra enkelte vigtige kirker og klostre hen mod hele senmiddelalderens brede vifte af kirkelige institutioner og formål. Inden for dette generelle billede har Samuel K. Cohn iagttaget nogle modifikationer af donationsmønstrene, han fortolker som en æendring af "the strategies of the afterlife« som følge af Den sorte Død omkring 1350: »investeringerne« $i$ frelsen koncentreredes om færre, men større donationer, der ofte forbandtes med et mindemæssigt præg, enten individcentreret eller familiebaseret. Med hensyn til mindefunktionen har vi set, at Birgers stiftelse ganske udpræget repræsenterer et eksempel på den »cult of remembrance $\ll$, Cohn har iagttaget i Italien. I hvilken udstrækning dette mindeaspekt er typisk for donationerne til kirken $i$ dansk senmiddelalder, må fremtidig forskning afgøre. Givet er det $\mathrm{i}$ hvert fald, at vi i dansk senmiddelalder finder en sameksistens mellem de mange små og spredte donationer og de få og store, en sameksistens, som ærkebisp Birger Gunnersen i Lund i øvrigt selv frembyder et udmærket eksempel på. I hans 


\section{Religiøs gavegivning i vesteuropæisk middelalder}

tilfælde har vi nemlig bevaret ikke blot det store fundationsdokument, hvormed omkring 90 bondegårde blev givet til en enkelt, storslået gudstjenestestiftelse, men også et testamente, i hvilket en hel stribe kirkelige institutioner - f.eks. samtlige klostre i ærkestiftet - betænkes med mindre gaver (Pontoppidan, 397-400).

De grundlæggende religiøse doktriner og trosforestillinger bag donationerne til kirken var ifølge den udenlandske forskning uændrede fra højmiddelalder til senmiddelalder. Intet materiale antyder, at dette skulle forholde sig anderledes for Danmarks vedkommende. Det er naturligvis klart, at Birger Gunnersens formulering af sine tanker omkring det at give gaver med henblik på sjælens frelse, som de findes i den store fundats for hans stiftelse fra 1512, er præget af hans personlighed og hans usædvanlige livsforløb. Alligevel vil jeg mene, at Birger her kun repræsenterer en individuel udformning af noget alment. Eamon Duffy har i bogen The Stripping of the Altars. Traditional Religion in England c.1400-c.1580 fra 1992 argumenteret for en grundlæggende identitet mellem kirkens religion og folkets religion i senmiddelalderen. I stedet for at tale om elitens - kirkens og teologernes over for folkets religion bruger han udtrykket »den traditionelle religion«, hvormed han vil angive, at der var tale om en religion, som alle delte, høj og lav, lægfolk og gejstlighed. Så vidt jeg kan se, er det præcis denne traditionelle religion, vi møder hos Birger Gunnersen. Som kirkemand var Birger i stand til at opstille et sofistikeret liturgisk program; men den grundlæggende religiøse tankegang bag hans gudstjenestestiftelse var baseret på en forholdsvis simpel opfattelse af forholdet mellem menneske og Gud, der havde princippet om do ut des som den centrale ide.

Dermed har jeg - for at vende tilbage til mit udgangspunkt - også i det danske kildemateriale påvist den centrale tankegang, der gør det relevant at inddrage Marcel Mauss' gavegivningsteori. Når Mauss er så velegnet til anvendelse på middelalderen, hænger det sammen med, at periodens egen tænkning omkring det at give gaver til religiøse formål ligger meget nær en formulering af kernen $i$ hans synspunkt: at givning af en gave sætter en udvekslingsproces i gang - også i forholdet mellem mennesket og det guddommelige. 


\section{Noter}

1. I det følgende refererer jeg - indsat $\mathrm{i}$ min egen ramme - relevante dele af et særdeles instruktivt fonedrag med titlen "The Medieval Gift as Agent of Social Bonds and Political Power: A Comparative Approach«, som den hollandske historiker Arnoud-Jan A. Bijsterveld holdt på International Medieval Congress II, University of Leeds, 11. juli 1995. Dr. Bijsterveld har venligst stillet en kopi af sit manuskript til min rådighed. En hollandsk version af hans foredrag vil blive offentliggiort i Tijdschrift voor Geschiedenis, $109,1996$.

2. Den formulering, jeg har brugt som overskrift p̊ artiklen, udtrykker det samme med et lidt andet ordvalg. Den stammer fra en jysk ridders indstiftelse af et vikardømme $i$ Lübeck i 1363 (Bisgaard, 103). Verbet »mageskifte (lat. commutare) tilhører ejendomshandlernes terminologi og anvendes $\mathbf{i}$ den situation, hvor man ikke køber eller sælger, men bytter gods af lige stor vardi.

3. Artiklen er et af en rakke forarbejder til en planlagt bog, der med arkebisp Birger Gunnersen som hovedperson skal forsøge at give en syntese af forholdet mellem religion og samfund $\mathrm{i}$ dansk senmiddelalder.

4. Det følgende bygger først $\mathrm{og}$ fremmest på det store fundationsdokument, "Sanctuarium Birgerianum « (Suhm, 1-89). Af tidligere biografier kan henvises til Bruun, 12-19; Ingesman 1990, 262-264.

\section{Litteratur}

Bay, Ole, "Donationeme til kirken i dansk senmiddelalder«, Per Ingesman og Jens Villiam Jensen, red., Danmark i Senmiddelalderen, Anus 1994, 317.341.

Bijsterveld, Arnoud-Jan A., "De middeleeuwse gift als instrument van sociale integratie en politieke machtsvorming. Een historiografisch overzicht«, Tijdschrift voor Geschiedenis, 109, 1996 (under udgivelse).

Bisgaard, Lars, Tjenesteideal og fromhedsideal. Studier $i$ adelens taenkemdde $i$ dansk senmiddelalder, Århus 1988.

Bouchard, Constance, Holy Entrepreneurs. Cistercians, Knights, and Economic Exchange in Twelfth-Century Burgundy, Ithaca/London 1991.

Bruun, Henry, Poul Laxmand og Birger Gunnersen. Studier over dansk politik $i$ arene omkring 1500, København 1959.

Cohn, Samuel K., Death and Property in Siena, 1205-1800. Strategies for the Afterlife, Baltimore/London 1988.

Cohn, Samuel K., The Cult of Remembrance and the Black Death. Six Renaissance Cities in Central Italy, Baltimore/London 1992.

Duffy, Eamon, The Stripping of the Altars. Traditional Religion in England c.1400-c.1580, New Haven/London 1992. 


\section{Religiøs gavegivning i vesteuropæisk middelalder}

Ingesman, Per, "Religiøs symbolik og sociale ambitioner. Den højere gejstligheds segl $\mathrm{i}$ dansk senmiddelalder «, Heraldisk Tidsskrift, VI, nr. 56, 1987, 283-300.

Ingesman, Per, "Sankt Jørgens alter i Lund, som kaldes Svendealteret “, Kongemagt og Samfund $i$ Middelalderen. Fesiskrift til Erik Ulsig, Århus 1988, 259-285.

Ingesman, Per, Rirkesadets godsadministration $i$ senmiddelalderen, Lund 1990.

Ingesman, Per, »Kirke og ejendom i dansk senmiddelalder eller Historien om en tro godsforvalter«, Ordet, kirken og kulturen. Afhandlinger om kristendomshistorie tilegnet Jakob Balling, Århus 1993, 141-164.

Jobert, Philippe, La notion de donation. Convergences: 630-750, Paris 1977.

Madsen, Mogens, Episcoporum ecclesia Lundensis, ed. Thomas Bartholin, København 1710.

Mauss, Marcel, "Essai sur le don. Forme et raison de l'échange dans les sociétés archaïques «, Année sociologique, 2e série, 1, 1923-24, 30-186 (optrykt i: Marcel Mauss, Sociologie et anthropologie, Se éd., Paris 1993).

McLaughlin, Megan, Consorting with Saints. Prayer for the Dead in Early Medieval France, Ithaca/London 1994.

Pontoppidan, Erik, Annales ecclesio Danica diplomatici, II, København 1744.

Rosenwein, Barbara H., To Be the Neighbor of Saint-Peter. The Social Meaning of Cluny's Property 909-1049, Ithaca/London 1989.

Suhm, P.F., Samlinger til den Danske Historie, 1,3, København 1779.

Ulsig, Erik, Art. »Donasjon. Danmark«, Kulturhistorisk Leksikon for Nordisk Middelalder, III, København 1958, 229-231.

Weibull, Lauritz, »Ärkebiskop Birgers gudstjenststiftelse i kryptkyrkan i Lund«, Historisk tidskrift för Skd̊neland, II, 1904-08, 273-293.

\section{Summary}

"To Exchange the Temporal with the Spiritual: Religious Gift-Giving in the Western European Middle Ages" - The main part of the article concentrates on a chantry founded in 1512 by Danish Archbishop Birger Gunnersen of Lund. The chantry was, by all standards, a magnificent enterprise: by the number of tenant farmsteads - about 90 - being given to the foundation; by the number of horae, masses, vigils, and anniversaries that were to be sung and read in the chantry; and, finally, by the number of individuals - more than a 100 are mentioned by name - for whose souls prayers were to be said during the masses. It is shown that the chantry has the sarcophagus of the archbishop as its centre, physically as well as liturgically. The chantry represents, therefore, the same "cult of remembrance" that Samuel $K$. Cohn has found in Italian renaissance cities after The Black Death. The foundation document, called \$Sanctuarium Birgerianum «, is analyzed in order to uncover the religious ideas behind the foundation. Here it is concluded that although the archbishop was able to set up a highly sophisticated liturgical programme, his personal religion was what Eamon Duffy calls »traditional religion «. It had a do ut des thinking as its central idea, and 
Per Ingesman

so this case study shows the relevance of using Marcel Mauss' theory of giff-giving in a Danish context.

\section{Per Ingesman}

Forskningslektor, lic.theol.

Institut for Kirkekundskab

Aarhus Universitet 